Maciej Kobak, Przemysław Niemczuk, Lech J. Żukowski*

\title{
DECENTRALIZACJA I FINANSOWANIE ZADAŃ Z ZAKRESU OCHRONY ZDROWIA PSYCHICZNEGO
}

\section{Wprowadzenie}

W tekście zaprezentowano wybrane zagadnienia związane $\mathrm{z}$ decentralizacją i finansowaniem zadań publicznych z zakresu ochrony zdrowia psychicznego. Strukturę przedstawianych tematów kształtują trzy części dotyczące odpowiednio:

1) decentralizacji zadań publicznych z zakresu ochrony zdrowia;

2) decentralizacji wybranych zadań z zakresu ochrony zdrowia psychicznego oraz

3) finansowania świadczeń opieki zdrowotnej z zakresu zdrowia psychicznego.

\section{Decentralizacja zadań publicznych ${ }^{1}$}

Początkowo decentralizacja była procesem mającym na celu wprowadzenie harmonijnego podziału władzy po okresie nadmiernej centralizacji. Prawie wszystkie kraje europejskie poznały w swej historii

Maciej Kobak, Przemysław Niemczuk, Lech J. Żukowski - doktorzy nauk prawnych, WSPiA Rzeszowska Szkoła Wyższa.

1 Autorem cz. 2 i 3 jest P. Niemczuk. 
unitarny i mocno scentralizowany system polityczny. Od lat 60. XX w. w poszczególnych krajach, z różnym nasileniem, pojawia się tendencja do decentralizacji. Proces ten zachodzi w kierunku przeobrażeń charakteryzujących się odchodzeniem od centralizacji. Jak trafnie zauważa J. Starościak, rozwijający się system prawa stale wnosi coś nowego do elementów określenia „decentralizacja”. Prawo i życie społeczne wypełniają powoli, acz nieprzerwanie nową treścią to pojęcie ${ }^{2}$.

Obecnie decentralizacja stanowi samodzielne rozwiązanie w organizacji administracji publicznej. Nie jest już jedynie metodą sprawowania władzy w państwie stanowiącą odejście od centralizacji ${ }^{3}$. Decentralizacja ewoluowała, stała się w pełni dojrzałą formą ustrojową, będącą obok centralizacji immanentną cechą ustroju państwa. Każde nowoczesne demokratyczne państwo prawa winno w swych podstawach lokować zasadę decentralizacji, nie negując jednocześnie roli centralizacji. Obie techniki powinny mieć swoje zastosowanie w ustrojowym porządku prawnym państwa, przy czym żadna z nich nie jest celem samym dla siebie. Błędem byłoby przeciwstawianie ich sobie. Szczególnie ważna zdaje się tu odpowiednia proporcja, którą wyznaczać powinny cele administracji publicznej, w tym także ukierunkowanych na ochronę zdrowia. Sposób na jej zachowanie powinien być efektem zastosowania zasady komplementarności oraz pomocniczości. „Między rządem a samorządem nie ma żadnych naturalnych przeciwieństw” - pisał ponad 70 lat temu M. Jaroszyński, „albowiem rząd i samorząd - to tylko [...] dwa odmiennie skonstruowane narzędzia, którymi posługuje się zorganizowana społeczność

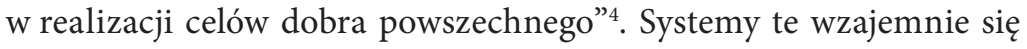
nie wykluczają, lecz uzupełniają, tworząc w całości funkcjonalne narzędzie realizacji zadań z zakresu ochrony zdrowia.

2 Zob. J. Starościak, Decentralizacja administracji, Warszawa 1960, s. 9.

3 Proces ten obrazuje pojawienie się w literaturze pojęcia niecentralizacji. O ile decentralizacja znamionuje odejście od standardów państwa o scentralizowanej administracji, o tyle niecentralizacja obrazuje tendencję do utrzymania naturalnej już samodzielności określonych jednostek terytorialnych. Por. H. Izdebski, M. Kulesza, Administracja publiczna. Zagadnienia ogólne, Warszawa 2004, s. 206.

${ }^{4}$ M. Jaroszyński, Wspótpraca z rządem w samorządzie, „Gazeta Polska” 1934/44, za: Z. Niewiadomski, Samorząd terytorialny w warunkach współczesnego państwa kapitalistycznego, Warszawa 1988, s. 31. 
Decentralizację często tłumaczy się jako przejmowanie zadań przez organy niższych szczebli, czyli jako dekoncentrację połączoną z jednoczesnym wyposażeniem tych organów w samodzielność i określoną niezależność. W dekoncentracji uprawnienia do decyzji są przekazywane organom podporządkowanym, a w decentralizacji - niezależnym, nienależącym do scentralizowanej administracji rządowej. Dekoncentracja przekazuje zadania, a decentralizacja - zadania i wła$\mathrm{dzę}^{5}$. W procesie dekoncentrowania kompetencje mogą być przekazywane także przez organ zwierzchni, w procesie decentralizowania mogą one być przekazywane wyłącznie w drodze ustawowej ${ }^{6}$. Z tak ujmowanej decentralizacji wynika motyw funkcjonalny. Opiera się na założeniu roli, jaką ma pełnić decentralizacja w funkcjonowaniu państwa i jego administracji w związku z realizacją zadań publicznych, w tym z zakresu ochrony zdrowia.

O decentralizacji można obecnie mówić jako o samoistnej metodzie organizacji administracji publicznej charakteryzującej się właściwymi jej przymiotami. Za istotę decentralizacji rozumie się przeważnie prawem określoną samodzielność organów niższego stopnia. Sfera tej samodzielności wynika z ograniczenia dopuszczalności ingerencji organu stopnia wyższego wyłącznie do ograniczonych prawem przypadków i tylko w oznaczony prawem sposób ${ }^{7}$. Warunkiem owej samodzielności są przewidziane w ustawie środki nadzoru. Mogą być one różne: sprowadzać się do funkcji kontroli legalności działań, uchylenia aktu prawnego sprzecznego z prawem, zawieszenia czy rozwiązania organu. Nigdy jednak nie może być tu zastosowana forma nakazu określonego działania, gdyż właśnie polecenie w sposób najintensywniejszy ogranicza samodzielność działania ${ }^{8}$.

Podstawową formą decentralizacji jest samorząd. Jego istotą jest powierzenie zarządu sprawami publicznymi, w tym także z zakresu ochrony zdrowia, samym zainteresowanym, czyli zrzeszeniom oby-

5 Zob. np. J. Szreniawski [w:] Ustrój administracji publicznej, red. J. Szreniawski, Lublin 1995, s. 11; H. Izdebski, M. Kulesza, Administracja..., s. 135.

6 Zob. J. Boć [w:] Prawo administracyjne, red. J. Boć, Wrocław 2000, s. 219.

7 Zob. J. Starościak, Decentralizacja..., s. 9 i n.

8 Zob. Z. Leoński, Zarys prawa administracyjnego, Warszawa 2004, s. 67. 
wateli, zorganizowanym z mocy ustawy w korporacjach prawa publicznego. Państwo jest związkiem publicznoprawnym wszystkich obywateli. Gmina, powiat czy województwo jest związkiem publicznoprawnym mieszkańców danego obszaru. Izby zaś (np. lekarska) to związki publicznoprawne oparte na kryterium zawodowym. Samorząd jest formą ustrojową wykonywania zarządu sprawami danej korporacji publicznoprawnej przez jej członków, przynależnych do niej z mocy samego prawa9 ${ }^{9}$ Zasadniczą i najważniejszą formą samorządu jest samorząd terytorialny.

Podział zadań między państwo a samorząd terytorialny jest istotnym elementem ustrojowej koncepcji przyjętej w konkretnym porządku normatywnym ${ }^{10}$. Stwierdzić przy tym należy, że zadania państwa i zadania samorządu tworzą jednorodną kategorię zadań publicznych mających państwowy charakter ${ }^{11}$. Dotyczy to także zadań z zakresu ochrony zdrowia. Znajduje to uzasadnienie w akceptowanej w nauce prawa administracyjnego tezie o niecelowości przeciwstawiania sobie państwa i samorządu ${ }^{12}$ oraz w uznawanej powszechnie państwowej teorii samorządu terytorialnego. Działalność organów samorządu terytorialnego nie zmierza więc do urzeczywistnienia własnych, naturalnych praw tego samorządu, lecz do spełniania celów i zadań o przymiocie państwowym. Prawo, któremu podlegają te organy i które wykonują, realizując zadania, jest prawem państwowym ${ }^{13}$. Działalność ta nie ma

9 Por. H. Izdebski, M. Kulesza, Administracja..., s. 136-137. Szerzej na temat pojęcia i rodzajów korporacji prawa publicznego zob. np. S. Fundowicz, Decentralizacja administracji publicznej w Polsce, Lublin 2005, s. 34 i n.

${ }_{10}$ Zob. J. Jeżewski, Podział kompetencji między samorząd terytorialny a państwo we Francji, ST 1992/3, s. 34.

${ }_{11}$ Por. np. Z. Niewiadomski, Polski samorząd terytorialny $w$ świetle standardów europejskich, ST 1992/11, s. 26; I. Lipowicz [w:] Konstytucje Rzeczypospolitej Polskiej oraz komentarz do Konstytucji RP z 1997 roku, red. J. Boć, Wrocław 1998, s. 256.

${ }^{12} \mathrm{~W}$ tym zakresie zob. np. A. Piekara, Wartość, istota, uwarunkowania i funkcje społeczne samorządu terytorialnego a rozwój lokalny [w:] Samorząd terytorialny a rozwój lokalny, red. A. Piekara, Z. Niewiadomski, Warszawa 1992, s. 21 i 29; K. Podgórski, Ustawowa regulacja zadań gmin jako jednostki samorządu terytorialnego, ST 1991/11-12, s. 20; I. Lipowicz [w:] Konstytucje..., s. 45; E. Olejniczak-Szałowska, Zadania własne i zlecone samorządu terytorialnego, ST 2000/12, s. 13.

13 Por. A. Wiktorowska, Prawne determinanty samodzielności gminy. Zagadnienia administracyjnoprawne, Warszawa 2002, s. 134. 
charakteru dobrowolnego, lecz poddana jest regulacji ustawowej. Oznacza to, że zobowiązanie lub uprawnienie organów samorządu terytorialnego do wykonywania zadań publicznych, w tym z zakresu ochrony zdrowia, może nastąpić ze względów politycznych, pragmatycznych czy funkcjonalnych, recypowanych do treści prawa ${ }^{14}$.

Istnienie jednorodności zadań publicznych samorządu i państwa znajduje potwierdzenie także w stanowisku Trybunału Konstytucyjnego ${ }^{15}$. W uchwale z 27.09.1994 r. ${ }^{16}$ Trybunał Konstytucyjny uznał, że „Wszystkie zadania samorządu terytorialnego mają charakter zadań publicznych w tym znaczeniu, że służą zaspokojeniu potrzeb zbiorowych społeczności czy to lokalnych, w wypadku zadań własnych, czy zorganizowanego w państwo całego społeczeństwa, jak w wypadku zadań zleconych”.

Celem prawidłowego wykonania zadania muszą być poddane repartycji pomiędzy państwo i jego organy rządowe a jednostki samorządu terytorialnego dysponujące własnym aparatem administracyjnym. Podział ten, w realiach kilkustopniowej struktury terenowej państwa, wymaga ponadto doprecyzowania poprzez wskazanie zadań właściwych dla poszczególnych szczebli administracji publicznej. Na tym samym poziomie część zadań należy do państwa, część zaś - do samorządu tery torialnego. Podział zadań w obu układach to - jak pisze W. Pańko - „skomplikowana sprawa podziału ról”17. Takiej także repartycji podlegają obecnie zadania z zakresu ochrony zdrowia.

\section{Ochrona zdrowia jako zadanie publiczne}

Prawo do ochrony zdrowia stanowi jedno z fundamentalnych praw człowieka, dlatego system ochrony zdrowia zajmuje bardzo ważne

${ }^{14}$ Por. E. Nowacka, Spór o pojęcie samorządu terytorialnego $w$ doktrynie prawnej okresu międzywojennego, ST 1992/4, s. 10.

15 Zob. np. orzeczenie TK z 23.10.1995 r., K 4/95, OTK 1995/2, poz. 11; orzeczenie TK z 13.11.1996 r., K 17/96, OTK 1996/5, poz. 43.

${ }^{16}$ Uchwała TK z 27.09.1994 r., W 10/93, OTK 1994/2, poz. 46.

17 Zob. W. Pańko, Nie przeceniam swojej roli, „Wspólnota” 1991/43, s. 3. 
miejsce w ogólnym systemie państwa. Z punktu widzenia dobra obywateli, opieka zdrowotna jest jednym z najważniejszych obszarów działań władz publicznych. W ustawodawstwie polskim nie ma jednolitego aktu prawnego systematyzującego wszystkie prawa w zakresie ochrony zdrowia. Podstawę w tej kwestii tworzą normy konstytucyjne ${ }^{18}$, w szczególności art. 68. Przepis ten ma podwójny charakter. Z jednej strony normuje prawa podmiotowe określonych osób (każdego - ust. 1; obywateli polskich - ust. 2; dzieci, kobiet ciężarnych, osób niepełnosprawnych i w podeszłym wieku - ust. 3), z drugiej zaś - wskazuje obowiązek działania władz publicznych ${ }^{19}$. Przekazywane przez ustawodawcę administracji publicznej zadania obejmują "ochronę zdrowia” i „promocję zdrowia”, wykonywane w ramach "polityki zdrowotnej” prowadzonej w celu zapewnienia równego dostępu do „świadczeń opieki zdrowotnej”. Aktualnie nie istnieją legalne definicje przytoczonych wyżej pojęć, co rzutuje na niespójny podział zadań i kompetencji administracji publicznej w zakresie ochrony i promocji zdrowia oraz wywołuje luki i niejednolitość prawa w tym obszarze ${ }^{20}$. Stan ten uznać należy za wymagający poprawy, w szczególności w sytuacji narastającego niezadowolenia społecznego z działalności organów administracji publicznej. Kształtuje to przekonanie o poważnych niedomaganiach administracji publicznej, prowadzących nieuchronnie do kryzysu w zaspokajaniu potrzeb społecznych, zwłaszcza w zakresie ochrony zdrowia $^{21}$.

18 Pamiętać jednak należy, iż obowiązek realizowania ochrony zdrowia przez władze publiczne wynika także z ratyfikowanych przez Polskę traktatów międzynarodowych, tj. Międzynarodowego Paktu Praw Obywatelskich i Politycznych otwartego do podpisu w Nowym Jorku 19.12.1966 r. (Dz.U. z 1977 r. Nr 38, poz. 167) oraz Konwencji o ochronie praw człowieka i podstawowych wolności sporządzonej w Rzymie 4.11.1950 r., zmienionej następnie Protokołami nr 3, 5 i 8 oraz uzupełnionej Protokołem nr 2 (Dz.U. z 1993 r. Nr 61, poz. 284).

19 P. Winczorek, Komentarz do Konstytucji Rzeczypospolitej Polskiej z 2.04.1997 r., Warszawa 2000, s. 91 i n.

${ }^{20}$ Por. M. Dercz, Samorząd terytorialny $w$ systemie ochrony zdrowia, Warszawa 2005, s. 11.

${ }^{21}$ Por. J. Posłuszny, O nowej koncepcji administracji świadczacej [w:] Aktualne problemy administracji i prawa administracyjnego, red. Z. Leoński, Z. Niewiadomski, J. Posłuszny, J. Stelmasiak, J. Szreniawski, K. Ziemski, L. Żukowski, Przemyśl-Rzeszów 2003, s. 301. 
Podstawowe znaczenie dla niniejszych rozważań ma zdefiniowanie pojęcia zdrowia ${ }^{22}$. Oczywiście definicja zdrowia jest uzależniona od dziedziny nauki, dla potrzeb której jest formułowana. Zważywszy na rangę oraz obszar obowiązywania w pierwszej kolejności wskazać należy definicję zawartą w Konstytucji Światowej Organizacji Zdrowia $(\mathrm{WHO})^{23}$ z 22.07.1946 r. Zdrowie zostało tutaj określone jako stan zupełnej pomyślności fizycznej, umysłowej i społecznej, a nie jedynie jako brak choroby lub ułomności ${ }^{24}$. Definicja ta odegrała znaczną rolę w kształtowaniu poglądów na temat zdrowia. Nie ogranicza się ona wyłącznie do wskazania braku choroby lub niedomagania, lecz w pozytywnym rozumieniu uwzględnia także stan pełnego dobrobytu, samopoczucia fizycznego, umysłowego i społecznego ${ }^{25}$. W efekcie definicję zdrowia pozbawiono wyłączności kryteriów medycznych, nadając jej również wartości społeczne. Definicja ta jednak stała się przedmiotem szerokiej krytyki. Główny zarzut dotyczy jej subiektywnych elementów składowych ${ }^{26}$ oraz niemożności rozwikłania podstawowych trudności metodologicznych związanych z precyzyjnym określenia pojęcia zdrowia ${ }^{27}$.

Pojawiły się także negatywne definicje zdrowia, dla których charakterystyczne jest traktowanie zdrowia jako braku choroby ${ }^{28}$. Według tego typu definicji zdrowie to wolność od fizycznej choroby i bólu ${ }^{29}$ lub też normalny stan organizmu, w którym nie występuje fizyczna lub psychiczna choroba, a wszystkie części organizmu pełnią swoje właściwe funkcje ${ }^{30}$. Powyższe definicje odnieść należy do konkretnej osoby, czyli do tzw. zdrowia jednostkowego. Pojęcie zdrowia wymaga

${ }^{22}$ Art. 5 pkt 28 ustawy z 4.09.1997 r. o działach administracji rządowej (Dz.U. z 2018 r. poz. 762) wprowadza dział „Zdrowie”.

${ }^{23}$ Na temat Światowej Organizacji Zdrowia zob. E. Latoszek, M. Proczek, Organizacje międzynarodowe. Założenia, cele, działalność, Warszawa 2001, s. 108 i n.

${ }^{24}$ Oficjalne tłumaczenie zawarte jest w Dz.U. z 1948 r. Nr 61, poz. 477 ze zm.

${ }^{25}$ Por. J. Indulski, J. Leowski, Podstawy medycyny społecznej, Warszawa 1971, s. 39.

${ }^{26}$ Por. Organizacja ochrony zdrowia, red. J. Indulski, Warszawa 1984, s. 73.

27 D. Callach, Health and Society: Same Ethical Imperatives, „Deadalus” 1977/106/1, s. 26.

${ }^{28}$ C. Włodarczyk, Polityka zdrowotna w społeczeństwie demokratycznym, Łódź-Kraków-Warszawa 1996, s. 108.

29 Webster's Medical Dictionary, Springfield 1986, s. 158.

${ }^{30}$ M. Crithley, Butterworths Medical Dictionary, London 1978, s. 784. 
bowiem rozróżnienia na zdrowie jednostkowe i zdrowie zbiorowości, które uznać należy za kategorię dość abstrakcyjną ${ }^{31}$. Alternatywnie używanymi w tym zakresie pojęciami są zdrowie narodu bądź zdrowie określonej wspólnoty, czy zdrowie pewnych kategorii społecznych (dzieci, młodzieży, kobiet, osób w wybranym przedziale wiekowym itd. $)^{32}$. Zdrowie jednostki i zbiorowości wzajemnie ze sobą korelują i są determinowane przez rozmaite czynniki ${ }^{33}$.

Kolejnym pojęciem nieposiadającym jednolitej definicji jest zdrowie publiczne. Klasyczna definicja zdrowia publicznego, sformułowana w 1935 r. przez C. Winslowa, zakładała, że pojęcie to oznacza wiedzę i sztukę służącą zapobieganiu chorobom, poprawie i przedłużaniu życia, zdrowia i witalności fizycznej i psychicznej jednostek poprzez określone działania zbiorowe ${ }^{34}$. Obecnie definicję tę należałoby wzbogacić jeszcze o promocję zdrowia. Zdrowie jednostki czy określonej zbiorowości stanowi istotną wartość społeczną, stąd też ogromny wpływ na prawidłowe funkcjonowanie państwa ma polityka zdrowotna. Przez pojęcie to należy rozumieć wszelką działalność państwa i innych podmiotów sprawujących władzę publiczną w zakresie polityki społecznej, nakierowaną na poprawę stanu zdrowia ludności oraz jednocześnie niedopuszczenie do jego pogorszenia ${ }^{35}$. Działalność ta winna być podejmowana według określonych kategorii, takich jak: profilaktyka, lecznictwo i rehabilitacja ${ }^{36}$. Podejmując próbę przybliżenia pojęcia polityki zdrowia, wskazać należy płaszczyzny jej realizacji. Podstawową płaszczyzną jest system ochrony zdrowia, obejmujący ogół podmiotów i instytucji powołanych w celu udzielenia świadczeń

${ }^{31}$ C. Włodarczyk, S. Paździoch, Pojęcie i zakres zdrowia publicznego [w:] Zdrowie publiczne, red. A. Czupryna, C. Włodarczyk, t. 1, Kraków 2000, s. 17.

${ }^{32}$ Zob. M. Dercz, Samorząd..., s. 13.

${ }^{33}$ Najbardziej znaną koncepcją wpływu czynników na zdrowie jest koncepcja „pól zdrowia”, zakładająca istnienie czterech pól (płaszczyzn) oddziałujących na zdrowie, związanych kolejno z: genetyką, środowiskiem przyrodniczym, zachowaniem jednostek i opieką zdrowotną. Por. M. Lalond, A New Perspective on Health of Canadians, a work document, Ministry of Supply and Services of Canada, Ottawa 1978, s. 7.

${ }^{34}$ The Future of Public Health, Committee for the Study of the Future of Public Health, Institute of Medicine, National Academy Press, Washington D.C. 1988, s. 39.

35 J. Nosko, Promocja zdrowia i ochrona zdrowia jako zadania własne samorzadu terytorialnego - cz. II, „Zdrowie Publiczne” 2000/5, s. 190 i n.

${ }^{36}$ L. Frąckiewicz, Polityka ochrony zdrowia - synteza, Katowice 1991, s. 5. 
zdrowotnych. Kolejną stanowią instytucje administrujące i finansujące służbę zdrowia. Ostatnia zaś jest tożsama z zakresem pojęciowym zdrowia publicznego ${ }^{37}$.

Zakres pojęciowy terminu „ochrona zdrowia” można ustalić w oparciu o szeroką analizę ogółu regulacji prawnych. W pierwszej kolejności należałoby skoncentrować się na Konstytucji RP, która poprzez brzmienie art. 68 szeroko ujmuje ochronę zdrowia ${ }^{38}$. Z jednej strony gwarantuje każdemu prawo do ochrony zdrowia, z drugiej zaś - nakłada na władzę publiczną obowiązek podejmowania działań mających na celu zapewnienie realizacji tego prawa. Szersze spojrzenie na omawiany termin pozwoli ujrzeć go w kilku znaczeniach: po pierwsze - jako ochronę przed chorobami przez zapobieganie i zwalczanie chorób zakaźnych, niezakaźnych o dużym wymiarze społecznym oraz innych chorób i niesprawności fizycznych i psychicznych, w ramach systemu opieki zdrowotnej; po drugie - jako ochronę przed zagrożeniami środowiska przyrodniczego, w ramach systemu ochrony zdrowia; po trzecie - ochronę przed zagrożeniami wynikającymi z niektórych warunków społecznych, w ramach polityki społecznej i edukacyjnej systemu opieki zdrowotnej, promocji zdrowia i pomocy społecznej ${ }^{39}$.

Można przyjąć, że system ochrony zdrowia stanowi wyodrębnioną całość złożoną z wielu różnorodnych elementów, powiązanych swoistymi więziami i relacjami, mającą cel związany ze zdrowiem ${ }^{40}$, realizowany w szczególności poprzez zapewnienie opieki zdrowotnej w każdym przypadku zachorowania, kalectwa, niesprawności, niedomagania, nie mówiąc już o zagrożeniach życia ${ }^{41}$. W krajach Organizacji Współpracy Gospodarczej i Rozwoju (OECD) system zdrowotny definiowany jest

${ }^{37}$ Por. C. Włodarczyk, Polityka..., s. 289.

${ }^{38}$ M. Dercz, H. Izdebski, Organizacja ochrony zdrowia w Rzeczypospolitej Polskiej w świetle obowiązującego ustawodawstwa, Warszawa-Poznań 2001, s. 11.

39 Zob. J. Nosko, Promocja zdrowia i ochrona zdrowia jako zadania własne samorzadu terytorialnego - cz. I, „Zdrowie Publiczne” 2000/4, s. 149.

${ }^{40}$ Zob. C. Włodarczyk, S. Paździoch, Systemy zdrowotne - zarys problematyki, Kraków 2001, s. 15.

${ }^{41}$ Por. J. Leowski, Polityka zdrowotna - dylematy i wyzwania reformy ochrony zdrowia w Polsce i na świecie, „Prawo i Medycyna” 1999/2, s. 46 i n. 
jako zorganizowana i zinstytucjonalizowana działalność społeczeństwa zawierająca wszystkie jego aktywności, których pierwotnym celem jest promowanie, odtwarzanie i utrzymywanie zdrowia ${ }^{42}$.

Szczególną rolę w systemie ochrony zdrowia pełni samorząd terytorialny ${ }^{43}$. Wynika to $\mathrm{z}$ istoty funkcjonowania zasady subsydiarności i decentralizacji w systemie administracji publicznej. Po reformie z 1999 r. głównym zadaniem samorządów terytorialnych wszystkich szczebli z zakresu ochrony zdrowia stało się przejęcie funkcji organizatora ochrony zdrowia, tj. funkcji organów założycielskich wszystkich publicznych zakładów opieki zdrowotnej ${ }^{44}$. Zadaniu temu przyporządkowano określone uprawnienia, które podzielić można na trzy grupy: organizacyjno-personalne, majątkowo-finansowe i kontrolno-nadzorcze ${ }^{45}$.

$\mathrm{W}$ ramach pierwszego $\mathrm{z}$ wymienionych uprawnień względem zakładów jednostkom samorządu terytorialnego przyznano prawo do: tworzenia, przekształcania, dokonywania połączeń lub podziałów, likwidacji, zatwierdzania statutu, zatrudniania (zwalniania) kierownika zakładu, powoływania rady społecznej oraz decydowania w pewnym zakresie o formie, w której zakład ma być prowadzony.

Drugą grupę uprawnień tworzą: uprawnienia do wyposażania zakładów w odpowiedni majątek oraz środki finansowe, jak również pozbawienie zakładów składników majątkowych, przy jednoczesnym uprawnieniu do określania zasad dysponowania przez zakłady ich mieniem oraz zasad zakupu lub przyjmowania darowizn aparatury i sprzętu medycznego. Jednostki samorządu terytorialnego posiadają także prawo do badania sprawozdania finansowego i do wyrażania zgody na wniesienie majątku zakładów do spółek lub fundacji.

${ }^{42}$ Zob. Zdrowie dla wszystkich $w$ XXI wieku, Centrum Systemów Informacyjnych Ochrony Zdrowia, Warszawa-Kraków 2001, s. 5-7.

${ }^{43}$ Zob. M. Kallas, I. Lipowicz, Z. Niewiadomski, G. Szpor, Prawo administracyjne. Część ustrojowa, Warszawa 2003, s. 126.

${ }^{44}$ Por. J. Nosko, Promocja zdrowia $i$ ochrona zdrowia jako zadania własne samorządu terytorialnego - cz. I, s. 191-192.

${ }^{45}$ M. Dercz, Samorząd..., s. 86 i n. 
Największe znaczenie ma jednak trzecia grupa uprawnień, tj. uprawnienia kontrolno-nadzorcze. W ramach uprawnień kontrolnych jednostki samorządu terytorialnego badają zakłady z punktu widzenia realizacji zadań statutowych, dostępności i poziomu udzielanych świadczeń, prawidłowości gospodarowania mieniem oraz gospodarki finansowej. Uprawnienie nadzorcze, którego zakres pojęciowy jest szerszy od kontroli, obejmuje swoim badaniem kwestię wykorzystania aparatury i sprzętu medycznego, wnioski dotyczące zakupu lub przyjęcia darowizny aparatury i sprzętu medycznego oraz wnioski dotyczące zbycia, wydzierżawienia lub wynajęcia majątku trwałego albo wniesienia tego majątku do spółki lub fundacji. W ograniczonym zakresie jednostki samorządu terytorialnego odgrywają także rolę płatnika w systemie ochrony zdrowia. Rola ta wynika $z$ uprawnienia organów tych jednostek do udzielania zamówienia na świadczenia zdrowotne podmiotom uprawnionym do ich udzielania. Ponadto jednostki samorządu terytorialnego mogą przekazywać samodzielnemu publicznemu zakładowi opieki zdrowotnej środki finansowe na określone cele, jak również udzielić mu dotacji na realizację konkretnych zadań.

\section{Decentralizacja zadań z zakresu zdrowia psychicznego w wybranych aktach prawnych ${ }^{46}$}

Obowiązki państwa związane z ochroną zdrowia psychicznego wpisują się w szeroki katalog zadań publicznych nakierowanych na ochronę zdrowia. W Konstytucji RP wprowadza się szereg praw związanych z tą sferą, do których zalicza się m.in.:

1) prawo do ochrony zdrowia,

2) prawo do równego dostępu do świadczeń opieki zdrowotnej finansowanych ze środków publicznych,

3) prawo do szczególnej opieki zdrowotnej dzieci, kobiet ciężarnych, osób niepełnosprawnych i osób w podeszłym wieku ${ }^{47}$.

${ }^{46}$ Autorem cz. 4 jest L.J. Żukowski.

${ }^{47}$ Tak stanowi art. 68 ust. 1-3 Konstytucji RP. 
Dodatkowo wprowadzono konstytucyjny wymóg dla władz publicznych niesienia pomocy osobom niepełnosprawnym w postaci zabezpieczania egzystencji, przysposobienia do pracy oraz komunikacji społecznej ${ }^{48}$. Mimo że te konstytucyjne prawa socjalne odnoszą się ogólnie do zdrowia oraz niepełnosprawności, to niewątpliwie dotyczą także wymiaru zdrowia psychicznego.

Zaliczenie zdrowia psychicznego do szerszego pojęcia zdrowia znajduje uzasadnienie w definicjach naukowych oraz konkretnych regulacjach prawnych. Wspomniane wyżej definicje wyraźnie włączają w zakres zdrowia sferę psychiczną. Analogiczną interpretację zdrowia psychicznego jako elementu szerszego kontekstu funkcjonowania psychosomatycznego można znaleźć w prawnych definicjach świadczeń zdrowotnych ${ }^{49}$. Można postawić więc tezę, że ilekroć jest mowa o zdrowiu, należy przez to rozumieć także zdrowie psychiczne ${ }^{50}$. Założenie to dotyczy także sfery normatywnej, pomimo faktu wyodrębnienia w systemie prawa administracyjnego aktów dotyczących wyłącznie zdrowia psychicznego ${ }^{51}$.

Zadania państwa, wymienione m.in. w art. 68 ust. 1-3 oraz art. 69 Konstytucji RP (choć nie wprost), dotyczą także zdrowia psychiczne-

48 Tak art. 69 Konstytucji RP.

49 Zob. definicję świadczeń zdrowotnych w: art. 2 ust. 1 pkt 10 ustawy z $15.04 .2011 \mathrm{r}$. o działalności leczniczej (Dz.U. z 2018 r. poz. 160 ze zm.), art. 5 pkt 40 ustawy z 27.08.2004 r. o świadczeniach opieki zdrowotnej finansowanych ze środków publicznych (Dz.U. z 2018 r. poz. 1510 ze zm.) dalej jako - u.ś.z.p. Zob. na ten temat M. Dercz, T. Rek, Ustawa o działalności leczniczej. Komentarz, LEX 2014.

${ }^{50} \mathrm{Na}$ temat powiązania funkcjonowania tzw. sfery biologicznej czy też somatycznej organizmu a ogólnego stanu zdrowia psychicznego zob. J.W. Kant, Biologiczne podstawy psychologii, Warszawa 2011, s. 3-8; A. Longstaff, Neurobiologia, Warszawa 2002, s. 95-139 oraz powołana tam literatura.

${ }^{51}$ Przykładowo w regulacjach dotyczących tzw. świadczeń gwarantowanych ochrona zdrowia psychicznego zaliczona została do szerszego katalogu świadczeń związanych z ochroną zdrowia (zob. art. 15 ust. 2 pkt 4 u.ś.z.p.). Ponadto, jak zauważa się $\mathrm{w}$ doktrynie, przedmiotem świadczeń zdrowotnych w polskim systemie prawnym jest również gwarancja prawidłowego rozwoju, uzyskania i utrzymania dobrej kondycji psychofizycznej, a więc optymalnego z punktu widzenia procesów życiowych stanu organizmu zarówno w aspekcie funkcji fizjologicznych, jak i psychicznych - tak J. Oniszczuk, Konstytucja Rzeczypospolitej Polskiej w orzecznictwie Trybunału Konstytucyjnego na początku XXI w., Kraków 2004, s. 342. 
go $^{52}$. Podobnie wiele aktów prawnych dedykowanych sferze ochrony zdrowia także w sposób pośredni odnosi się do zdrowia psychicznego ${ }^{53}$. Aktem w całości dotyczącym tej sfery jest ustawa z 19.08.1994 r. o ochronie zdrowia psychicznego ${ }^{54}$. Ponadto można wskazać inne ustawy, które ściśle łączą się z zadaniami publicznymi nakierowanymi na ochronę zdrowia psychicznego, takie jak ustawa z 29.07.2005 r. o przeciwdziałaniu narkomanii ${ }^{55}$ oraz ustawa z 26.10 .1982 r. o wychowaniu w trzeźwości i przeciwdziałaniu alkoholizmowi ${ }^{56}$. W kontekście omawianej problematyki ważna jest także ustawa z 11.09.2015 r. o zdrowiu publicznym ${ }^{57}$ oraz ustawa z 12.03 .2004 r. o pomocy społecznej ${ }^{58}$. Na mocy pierwszej z wymienionych ustaw wprowadza się wymóg uchwalania określonych programów związanych z ochroną zdrowia psychicznego (tj. uzależnieniami), z kolei ustawa o pomocy społecznej w sposób systemowy odnosi się także do pomocy osobom z zaburzeniami psychicznymi.

Na mocy tych ustaw oraz wydanych na ich podstawie aktów wykonawczych ukształtowany został system ochrony zdrowia psychicznego w polskim porządku prawnym ${ }^{59}$. Zadania związane z ochroną zdro-

${ }^{52}$ Należy wskazać, że w ścisłym związku ze sferą ochrony zdrowia psychicznego pozostaje także art. 30 Konstytucji RP.

${ }^{53}$ Choćby: ustawa z 15.04.2011 r. o działalności leczniczej (Dz.U. z 2018 r. poz. 160 ze zm.), ustawa o świadczeniach opieki zdrowotnej finansowanych ze środków publicznych, ustawa z 6.11.2008 r. o prawach pacjenta i Rzeczniku Praw Pacjenta (Dz.U. z 2017 r. poz. 1318 ze zm.), ustawa z 9.11.1995 r. o ochronie zdrowia przed następstwami używania tytoniu i wyrobów tytoniowych (Dz.U. z 2018 r. poz. 1446) czy też ustawa z 27.06.1997 r. o służbie medycyny pracy (Dz.U. z 2018 r. poz. 1155 ze zm.).

54 Dz.U. z 2018 r. poz. 1878 - dalej jako: u.o.p.

55 Dz.U. z 2018 r. poz. 1030 ze zm. - dalej jako: u.n.

${ }^{56}$ Dz.U. z 2016 r. poz. 487 ze zm. - dalej jako: u.w.t.

57 Dz.U. z 2018 r. poz. 1492 - dalej jako: u.z.p.

58 Dz.U. z 2018 r. poz. 1508 ze zm. - dalej jako: u.p.s.

59 Głównie ustawy o ochronie zdrowia psychicznego, o przeciwdziałaniu narkomanii, o wychowaniu w trzeźwości i przeciwdziałaniu alkoholizmowi. Treść ustawy o zdrowiu publicznym w znacznie skromniejszym zakresie odnosi się do zdrowia psychicznego. Wymienione ustawy nie wyczerpują przykładów aktów prawnych dotyczących sfery ochrony zdrowia psychicznego. W sposób mniej lub bardziej pośredni do problematyki tej odnoszą się takie ustawy, jak: ustawa z 9.11.1995 r. o ochronie zdrowia przed następstwami używania tytoniu i wyrobów tytoniowych (Dz.U. z 2018 r. poz. 1446), ustawa z 27.06.1997 r. o służbie medycyny pracy (Dz.U. z 2018 r. 1155 ze zm.). W zakresie praktycznym do sfery zdrowia psychicznego odwołuje się szereg ustaw związa- 
wia psychicznego, analogicznie do innych praw socjalnych, zostały $\mathrm{w}$ istotnym zakresie zdecentralizowane. Zależnie od przedmiotu regulacji różny jest zakres decentralizacji oraz jej charakter. Poniższa próba syntezy będzie obejmować wybrane akty prawne, w których zdecentralizowano na rzecz samorządu terytorialnego zadania z zakresu ochrony zdrowia psychicznego.

\subsection{Decentralizacja zadań z zakresu zdrowia psychicznego w ustawie o ochronie zdrowia psychicznego}

Konstytucyjna odpowiedzialność państwa za zadania publiczne związane z ochroną zdrowia psychicznego została wprost wyrażona w art. 1 ust. 1 u.o.p. Zaakcentowanie już w pierwszej jednostce redakcyjnej obowiązku zapewniania ochrony zdrowia psychicznego przez organy administracji rządowej i samorządowej wskazuje na wagę konkretnego dobra prawnego ${ }^{60}$. Ustawodawca w analogiczny sposób wskazał odpowiedzialność organów administracji rządowej i samorządowej za zadnia ściśle związane ze zdrowiem psychicznym w art. 1 u.w.t. oraz art. 1 ustawy o ochronie zdrowia przed następstwami używania tytoniu i wyrobów tytoniowych. Wymienione rozwiązania legislacyjne, szczególnie w kontekście ustawy o ochronie zdrowia psychicznego, są formą realizacji art. 15 Konstytucji RP. Bezpośrednim wskazaniem na decentralizację wybranych zadań z zakresu ochrony zdrowia jest jednak art. 2 ust. 4 pkt 1 u.o.p.

nych $\mathrm{z}$ funkcjonowaniem w służbach mundurowych, np. ustawa z 6.04.1990 r. o Policji (Dz.U. z 2017 r. poz. 2067 ze zm.), ustawa z 9.06.2006 r. o Centralnym Biurze Antykorupcyjnym (Dz.U. z 2017 r. poz. 1993 ze zm.), ustawa z 12.10.1990 r. o Straży Granicznej (Dz.U. z 2017 r. poz. 2365 ze zm.). Natomiast w kontekście diagnozy określonych predyspozycji związanych ze zdrowiem psychicznym np. ustawa z 5.01.2011 r. o kierujących pojazdami (Dz.U. z 2017 r. poz. 978 ze zm.) czy ustawa z 21.05.1999 r. o broni i amunicji (Dz.U. z 2017 r. poz. 1839 ze zm.).

${ }^{60} \mathrm{~W}$ kontekście ochrony w prawie administracyjnym dobra, jakim jest zdrowie, zob. Z. Duniewska [w:] Dobra chronione w prawie administracyjnym, red. Z. Duniewska, Łódź 2014, s. 16; J. Wegner-Kowalska, Zdrowie człowieka jako przedmiot ochrony prawa administracyjnego [w:] Dobra..., red. Z. Duniewska, s. 85-96; D. Tykwińska-Rutkowska, Ochrona życia i zdrowia człowieka w prawie administracyjnym (przyczynek do dyskusji) [w:] Dobra..., red. Z. Duniewska, s. 75-84. 
W art. 2 ust. 1 pkt 2-3 u.o.p. wprost wskazano działania związane ze zdrowiem psychicznym wyznaczone Narodowemu Programowi Ochrony Zdrowia Psychicznego ${ }^{61}$. Zaliczono do nich:

1) zapewnienie osobom $z$ zaburzeniami psychicznymi wielostronnej i powszechnie dostępnej opieki zdrowotnej oraz innych form opieki i pomocy niezbędnych do życia w środowisku rodzinnym i społecznym;

2) kształtowanie wobec osób z zaburzeniami psychicznymi właściwych postaw społecznych, a zwłaszcza zrozumienia, tolerancji, życzliwości, a także przeciwdziałania ich dyskryminacji.

Natomiast zadania związane z promocją zdrowia psychicznego i zapobieganiem zaburzeniom psychicznym, zgodnie z ustawą o ochronie zdrowia psychicznego, mają być realizowane w Narodowym Programie Ochrony Zdrowia ${ }^{62}$.

W NPOZP powtórzono delegację art. 2 ust. 4 pkt 1 u.o.p. przez wskazanie, że podmiotami biorącymi udział w jego realizacji są samorządy województw, powiatów i gmin. Podział zadań wynikających z NPOZP wskazuje na enumeratywnie wymienione podmioty odpowiedzialne za ich realizację. Odnośnie do zadań zdecentralizowanych na rzecz samorządu terytorialnego wprost wymienia się tylko samorząd województwa i powiatu. W pkt X NPOZP wprowadza się kategorię jednostek samorządu terytorialnego, do których należy zaliczyć gminy, zgodnie $\mathrm{z}$ art. 164 ust. 1 Konstytucji $\mathrm{RP}^{63}$.

${ }^{61}$ Rozporządzenie Rady Ministrów z 8.02.2017 r. w sprawie Narodowego Programu Ochrony Zdrowia Psychicznego na lata 2017-2022 (Dz.U. poz. 458) - dalej jako: NPZ.

${ }^{62}$ Rozporządzenie Rady Ministrów z 4.08.2016 r. w sprawie Narodowego Programu Zdrowia na lata 2016-2020 (Dz.U. poz. 1492) - dalej jako: NPOZ. Na temat aktów planowania w prawie administracyjnym zob. M. Stahl, Szczegółowe prawne formy działania administracji [w:] System Prawa Administracyjnego, t. 5, Prawne formy działania administracji, red. R. Hauser, Z. Niewiadomski, A. Wróbel, Warszawa 2013, s. 364-373.

${ }_{63}$ W kwestii techniki legislacyjnej powstaje pytanie, dlaczego w NPOZP nie posłużono się nazwą "gmina”, zastępując ją określeniem „jednostka samorządu terytorialnego". We wstępie omawianego aktu terminologicznie wprowadza się pojęcia samorządu województwa, powiatu i gminy, a nie jednostek samorządu regionalnego, lokalnego i terytorialnego. Jest to jednak wyłącznie niekonsekwencja terminologiczna. 
Katalog zadań zdecentralizowanych na rzecz samorządu w NPOZP jest zróżnicowany. Najwięcej zadań przypisanych jest województwu, a najmniej gminie - powiat lokuje się pośrodku tej skali. Wspólnym mianownikiem zadań wyznaczanych jednostkom samorządu jest zapewnianie osobom z zaburzeniami psychicznymi wielostronnej opieki adekwatnej do ich potrzeb. Zadanie to jest powtórzeniem obowiązku wynikającego z art. 6 u.ś.z.p. oraz art. 7-9 powołanej ustawy w kontekście zadań poszczególnych szczebli samorządu terytorialnego, lokalnego i regionalnego. Zadania własne samorządu terytorialnego określone w ustawie o świadczeniach zdrowotnych finansowanych ze środków publicznych mają głównie charakter planistyczny, profilaktyczny i edukacyjny (dot. powiatu). Zadania wynikające z NPOZP mają zbliżony charakter do tych określonych ustawą o świadczeniach zdrowotnych.

W NPOZP najbardziej rozbudowano zadania samorządu województwa. Wprowadzono cztery cele szczegółowe, tj.:

1) upowszechnienie środowiskowego modelu psychiatrycznej opieki;

2) upowszechnienie zróżnicowanych form pomocy i oparcia społecznego;

3) aktywizacja zawodowa osób z zaburzeniami psychicznymi oraz

4) skoordynowanie dostępnych form opieki i pomocy.

Do istotniejszych zadań delegowanych samorządowi województwa należą działania wiążące się z organizacją Centrum Zdrowia Psychicznego (CZP). Doniosły charakter mają również zadania wiążące się z koordynacją form opieki pomocy, w związku z którą samorząd województwa jest odpowiedzialny za:

1) opracowanie lub aktualizację regionalnego programu ochrony zdrowia psychicznego;

2) realizację, koordynowanie i monitorowanie regionalnego programu ochrony zdrowia psychicznego w odniesieniu do zadań wskazanych dla samorządu województwa;

3) przygotowanie aktualizowanego corocznie przewodnika informującego o dostępnych formach opieki zdrowotnej, pomocy społecznej i aktywizacji zawodowej dla osób z zaburzeniami psychicznymi, w tym w oparciu o informacje przekazane przez samorządy powiatowe. 
Szczegółowe zadania powiatu określone zostały analogicznie do szczegółowych celów wyznaczonych województwu, z tym że realizacja tych zadań odbywa się na szczeblu lokalnym. Ważnym zadaniem jest utworzenie CZP zgodnie z zasadami organizacyjnymi zawartymi w rozdziale 4 NPOZP. Powiat jest także jedyną jednostką samorządu, dla której wprowadzono tzw. wskaźnik monitorujący dla planowanego celu. Dotyczy on upowszechnienia środowiskowego modelu psychiatrycznej opieki zdrowotnej. W NPOZP wskaźnikiem tym ma być odsetek placówek biorących udział w programie w okresie roku.

Najwęziej określone zostały zadania gminy. Zgodnie z NPOZP do zadań gminy należą m.in.:

1) zapewnienie osobom z zaburzeniami psychicznymi wielostronnej opieki adekwatnej do ich potrzeb;

2) wspieranie rozwoju dzieci i młodzieży przez poradnie psychologiczno-pedagogiczne przez udzielanie dzieciom i młodzieży oraz rodzicom pomocy psychologiczno-pedagogicznej oraz

3) udzielanie pomocy psychologiczno-pedagogicznej dzieciom i młodzieży w przedszkolach, szkołach i placówkach.

Zawężenie kompetencji gminy nie świadczy o mniejszej roli zdecentralizowanych zadań. Istota funkcjonowania podstawowej jednostki samorządu terytorialnego zapewnia realizację podstawowych potrzeb związanych z ochroną zdrowia psychicznego w sposób najbardziej dopasowany do ich charakteru.

\subsection{Decentralizacja zadań z zakresu zdrowia psychicznego w ustawie o przeciwdziałaniu narkomanii}

Zgodnie z art. 5 ust. 1 u.n. zadania w zakresie przeciwdziałania narkomanii wykonywane są m.in. przez jednostki samorządu terytorialnego. Są one realizowane przez odpowiednie kształtowanie polityki społecznej, gospodarczej, oświatowo-wychowawczej i zdrowotnej. W ustawie wymienia się jedynie przykładowe formy tak rozumianych przeciwdziałań, do których należą m.in. edukacja, profilaktyka, leczenie, rehabilitacja czy ograniczanie szkód zdrowotnych i społecz- 
nych wynikających z narkomanii ${ }^{64}$. Ustawa definiuje narkomanię jako stałe lub okresowe używanie w celach innych niż medyczne środków odurzających, substancji psychotropowych, środków zastępczych lub nowych substancji psychoaktywnych, w wyniku czego może powstać lub powstało uzależnienie ${ }^{65}$. Definicja ta jest zbieżna z psychopatologicznym obrazem uzależnienia oraz nozologicznym opisem zaburzeń psychicznych polegających na nadużywaniu substancji psychoaktywnych ${ }^{66}$. Przeciwdziałanie narkomanii jest więc jedną $\mathrm{z}$ form ochrony zdrowia psychicznego i zdrowia w ogóle.

W regulacjach ustawy o przeciwdziałaniu narkomanii zdecentralizowane zadania związane $\mathrm{z}$ ochroną zdrowia psychicznego pozostają w związku z treścią Narodowego Programu Zdrowia (zob. art. 7 u.n.). Omawiana ustawa wymienia w zasadzie dwie jednostki samorządu, tj. województwo i gminę ${ }^{67}$; to właśnie one mają realizować szczegółowo określone zadania ${ }^{68}$. Do najważniejszych z nich należy zaliczyć obowiązki województwa i gminy związane z opracowaniem Wojewódzkiego Programu i Gminnego Programu Przeciwdziałania Narkomanii. Plany te mają uwzględniać cele operacyjne dotyczące przeciwdziałania narkomanii określone w NPZ. W ramach struktury urzędu marszałkowskiego ma zostać powołany ekspert do spraw informacji o narkotykach i narkomanii. Do jego kompetencji należy m.in.: zbieranie, gromadzenie, wymiana informacji i dokumentacji w zakresie przeciwdziałania narkomanii, prowadzenie i inicjowanie badań dotyczących problemów narkotyków i narkomanii oraz opracowywanie i udostępnianie ich wyników czy gromadzenie i udostępnianie publikacji na temat narkotyków i narkomanii ${ }^{69}$.

${ }^{64}$ Zob. art. 2 ust. 1 u.n.

${ }_{65}$ Tak art. 4 pkt 11 u.n.

${ }^{66}$ Zob. M. Seligman, E. Walker, D. Rosenhan, Psychopatologia, Poznań 2003, s. $616-685$.

${ }^{67} \mathrm{Z}$ wyjątkiem treści art. 5 ust. 2 pkt 7 u.n., gdzie do podmiotów realizujących zadania w zakresie ustawy włączono m.in. powiatowe centra pomocy rodzinie.

${ }_{68}$ Rola powiatu sprowadza się tu w zasadzie do organizacji administracji zespolonej i kompetencji Powiatowego Inspektora Sanitarnego.

${ }^{69}$ Zob. art. 9 ust. 2 pkt 7 u.n. 
Ustawa deleguje gminie zadania $\mathrm{z}$ szerokiego zakresu form przeciwdziałania narkomanii, które określone zostały w art. 2 ust. 1 u.n. Zgodnie z treścią art. 10 ust. 1 u.n. gmina realizuje je jako zadania własne. Obowiązkami gminy są:

1) zwiększanie dostępności pomocy terapeutycznej i rehabilitacyjnej dla osób uzależnionych i osób zagrożonych uzależnieniem;

2) udzielanie rodzinom, w których występują problemy narkomanii, pomocy psychospołecznej i prawnej;

3) prowadzenie profilaktycznej działalności informacyjnej, edukacyjnej oraz szkoleniowej w zakresie rozwiązywania problemów narkomanii, w szczególności dla dzieci i młodzieży, w tym prowadzenie zajęć sportowo-rekreacyjnych dla uczniów, a także działań na rzecz dożywiania dzieci uczestniczących w pozalekcyjnych programach opiekuńczo-wychowawczych i socjoterapeutycznych;

4) wspomaganie działań instytucji, organizacji pozarządowych i osób fizycznych, służących rozwiązywaniu problemów narkomanii;

5) pomoc społeczna osobom uzależnionym i rodzinom osób uzależnionych dotkniętym ubóstwem i wykluczeniem społecznym $\mathrm{i}$ integrowanie ze środowiskiem lokalnym tych osób z wykorzystaniem pracy socjalnej.

Wymienione zadania muszą być objęte Gminnym Programem Przeciwdziałania Narkomanii ${ }^{70}$, który jednocześnie stanowi część gminnej strategii rozwiązywania problemów społecznych. Dodatkowo w ustawie wprowadzono możliwość powoływania pełnomocnika wójta (burmistrza, prezydenta miasta) do realizacji zadań określonych w art. 10 ust. 1 u.n. Zarówno gmina, jak i województwo są zobligowane do składania stosownych raportów dotyczących wykonania Wojewódzkiego Programu i Gminnego Programu Przeciwdziałania Narkomanii ${ }^{71}$.

Charakter zadań związanych z przeciwdziałaniem narkomanii, które zostały zdecentralizowane na rzecz samorządu terytorialnego, wskazuje na kompetencje planistyczne województwa i gminy. Interwen-

70 Zob. art. 10 u.n.

${ }^{71}$ Tak art. 11 u.n. Raport ten przedkłada się odpowiednio sejmikowi województwa lub radzie gminy. 
cyjne formy przeciwdziałania narkomanii zostały oddelegowane gminie $\mathrm{w}$ formie zadań zleconych (zob. art. 52 u.n.). Warto dodać, że wójt (burmistrz, prezydent miasta) wykonuje istotne zadania z zakresu przeciwdziałania narkomanii związane z uprawami maku lub konopi włóknistych. Na podstawie ustawy o przeciwdziałaniu narkomanii wójt:

1) wydaje zezwolenia na uprawę maku lub konopi włóknistych i

2) sprawuje nadzór nad uprawami maku lub konopi włóknistych ${ }^{72}$.

Zadania te są jednak wykonywane przez gminę jako zadania zlecone z zakresu administracji rządowej ${ }^{73}$.

Decentralizacja zadań związanych z przeciwdziałaniem narkomanii odbywa się także przez regulacje ustawy o pomocy społecznej ${ }^{74}$, na mocy których istotnie wzrasta rola powiatu ${ }^{75}$. Mowa tu m.in o interwencji kryzysowej (art. 19 pkt 12 u.p.s.) oraz prowadzeniu i rozwijaniu infrastruktury ośrodków wsparcia dla osób z zaburzeniami psychicznymi (art. 20 ust. 1 pkt 2 u.p.s.). Wymienione zadania pośrednio łączą się także z problemami osób uzależnionych od środków odurzających lub substancji psychotropowych ${ }^{76}$.

\subsection{Decentralizacja zadań z zakresu zdrowia psychicznego w ustawie o wychowaniu w trzeźwości i przeciwdziałaniu alkoholizmowi}

Ustawodawca akcentuje doniosłość problemów objętych regulacjami ustawy o wychowaniu w trzeźwości i przeciwdziałaniu alkoholizmowi przez wprowadzenie preambuły ${ }^{77}$. Życie obywateli w trzeźwości ma

72 Tak art. 47 i 51 u.n.

${ }^{73}$ Zob. art. 52 u.n.

${ }_{74}$ Zob. art. 7 pkt 13, art. 16 ust. 1 i 2, art. 17, 19 i 21 u.p.s.

75 Mowa tu m.in. o interwencji kryzysowej (art. 19 pkt 12 u.p.s.) oraz prowadzenie i rozwój infrastruktury ośrodków wsparcia dla osób z zaburzeniami psychicznymi (art. 20 ust. 1 pkt 2 u.p.s.).

76 Zob. art. 4 pkt 29 u.n.

${ }^{77} \mathrm{Na}$ temat roli preambuł w aktach prawnych i ich aksjologicznego charakteru zob. J. Boć, P. Lisowski, Normatywizacja wartości w prawie administracyjnym [w:] War- 
stanowić zgodnie z ustawą niezbędny warunek moralnego i materialnego dobra narodu. Abstrahując od aksjologicznej doniosłości treści preambuły $^{78}$, wskazuje ona na wagę problemu nadużywania alkoholu w społeczeństwie. Normatywizacja ochrony wartości, jaką jest tzw. trzeźwość narodu, odbywa się także przez decentralizację zadań publicznych.

Ustawa określa, że jednostki samorządu terytorialnego (wspólnie z organami administracji rządowej) są zobligowane m.in. do podejmowania działań zmierzających do ograniczania spożycia napojów alkoholowych, popierania, tworzenia i rozwoju organizacji społecznych, których celem jest krzewienie trzeźwości i abstynencji, oddziaływanie na osoby nadużywające alkoholu oraz udzielanie pomocy ich rodzinom ${ }^{79}$. Przeciwdziałanie alkoholizmowi odbywa się zgodnie z założeniami NPZ przez kształtowanie programów polityki społecznej, które określa art. 2 ust. 1 pkt 1-8 u.w.t. Podobnie jak w kontekście przeciwdziałania narkomanii na mocy ustawy o wychowaniu w trzeźwości i przeciwdziałaniu alkoholizmowi decentralizacja zadań na rzecz jednostek samorządu ma charakter właściwych programów, określonych $\mathrm{w}$ art. 4 ust. 1-4 i art. $4^{1}$ ust. 1-2 u.w.t.

Zarząd województwa koordynuje i przygotowuje wojewódzki program profilaktyki i rozwiązywania problemów alkoholowych, stanowiący część strategii województwa w zakresie polityki społecznej. Program uwzględnia zadania określone w art. 1 i 2 u.w.t. oraz cele operacyjne dotyczące walki z alkoholizmem określone w NPZ. Dodatkowo województwo ma udzielać pomocy merytorycznej instytucjom i osobom fizycznym realizującym zadania objęte tym programem oraz współdziałać z innymi organami administracji publicznej w zakresie rozwiązywania

tości $w$ prawie administracyjnym, red. J. Zimmermann, Warszawa 2015, s. 27; S. Lewandowski, Kontrowersje wokół preambut, „Studia Iuridica” 1996/31, s. 88-95; wyrok NSA z 16.10.1984 r., SA/Wr 384/84, ONSA 1984/2, poz. 90; wyrok TK z 11.05.2007 r., K 2/07, OTK-A 2007/5, poz. 48; K. Complak, Preambuły do konstytucji [w:] Prawniczy słownik wyrazów trudnych, red. J. Boć, Wrocław 2005, s. 284 i n.

78 Warto zastanowić się, czy brzmienie preambuły ustawy o wychowaniu w trzeźwości i przeciwdziałaniu alkoholizmowi nie cechuje się zbytnią „pompatycznością”.

79 Zob. art. 1 ust. 1 u.w.t. 
problemów alkoholowych ${ }^{80}$. Ważnym zadaniem województwa jest organizacja na obszarze województwa podmiotów wykonujących działalność leczniczą w postaci stacjonarnych i całodobowych świadczeń zdrowotnych w zakresie leczenia odwykowego. Zarząd województwa organizuje także wojewódzki ośrodek terapii uzależnienia i współuzależnienia.

W ustawie zdecentralizowano na rzecz gmin działania z zakresu profilaktyki i rozwiązywania problemów alkoholowych oraz integracji społecznej osób uzależnionych od alkoholu. Otwarty katalog zadań wchodzących w zakres tych działań wymienia m.in:

1) zwiększanie dostępności pomocy terapeutycznej i rehabilitacyjnej dla osób uzależnionych od alkoholu;

2) udzielanie rodzinom, w których występują problemy alkoholowe, pomocy psychospołecznej i prawnej, a w szczególności ochrony przed przemocą w rodzinie;

3) prowadzenie profilaktycznej działalności informacyjnej i edukacyjnej w zakresie rozwiązywania problemów alkoholowych i przeciwdziałania narkomanii.

Interpretacja art. $4^{1}$ ust. 1 pkt 3 u.w.t. wskazuje na konieczność koordynowania przez gminę zadań z zakresu profilaktyki i przeciwdziałania uzależnieniom, $\mathrm{tj}$. od:

1) alkoholu i

2) innych środków odurzających, substancji psychotropowych, środków zastępczych lub nowych substancji psychoaktywnych.

Podobnie jak w kontekście województwa katalog działań związanych z przeciwdziałaniem alkoholizmowi jest realizowany w postaci gminnego programu profilaktyki i rozwiązywania problemów alkoholowych, stanowiącego część strategii rozwiązywania problemów społecznych, uwzględniającego cele określone w NPZ.

Należy dodać, że w zakresie przeciwdziałania alkoholizmowi istotne kompetencje posiadają gminne komisje rozwiązywania problemów

${ }^{80}$ Programy mogą, ale nie muszą być realizowane przez regionalne ośrodki pomocy społecznej; zob. art. 4 ust. 3 u.w.t. 
alkoholowych. Komisje te, poza zakresem ujętym w art. $4^{1}$ ust. 1 pkt 1-7 u.w.t., są właściwe w sprawach: opiniowania wydawanych przez wójta (burmistrza, prezydenta miasta) zezwoleń na sprzedaż napojów alkoholowych przeznaczonych do spożycia w miejscu lub poza miejscem sprzedaży, kontroli przestrzegania zasad i warunków korzystania z zezwolenia (członkowie komisji), a także kierują na badania, o których mowa w art. 24 u.w.t.

W ustawie o wychowaniu w trzeźwości i przeciwdziałaniu alkoholizmowi znajdują się także bezpośrednie odwołania do powiatu. Warto wspomnieć, że zarządy województw mogą zlecać powiatom w drodze porozumień zadania z zakresu profilaktyki i rozwiązywania problemów alkoholowych oraz przekazywać środki finansowe na ich realizację. Starosta powiatu jest zobligowany do organizacji lecznictwa odwykowego przez organizację podmiotów innych niż te wymienione w art. 22 ust. 1 u.w.t. Dodatkowo organy powiatu mogą organizować i prowadzić izby wytrzeźwień. Podobnie jak w przypadku przeciwdziałania narkomanii powiat realizuje zadania związane z przeciwdziałaniem alkoholizmowi na mocy regulacji ustawy o pomocy społecznej ${ }^{81}$. Inne zadania samorządów związane z przeciwdziałaniem alkoholizmowi są wymieniane także w art. 17 ust. 1 pkt 1 u.p.s. oraz w art. 21 u.p.s.

Syntetyczne przedstawienie decentralizacji zadań z zakresu ochrony zdrowia psychicznego na przykładzie wybranych ustaw pozwala na postawienie kilku wniosków, tj.:

1) zakres zadań wyznaczanych samorządowi terytorialnemu wpisuje się w systemową ochronę zdrowia psychicznego, a regulacje ustaw o ochronie zdrowia psychicznego, o przeciwdziałaniu narkomanii i o wychowaniu w trzeźwości i przeciwdziałaniu alkoholizmowi są komplementarne z treścią innych aktów dotyczących tej problematyki ${ }^{82}$;

${ }^{81}$ Np. art. 19 pkt 2 u.p.s. czy art. 19 pkt 12 u.p.s. Do zadań z zakresu administracji rządowej realizowanych przez powiat należy m.in. prowadzenie i rozwój infrastruktury ośrodków wsparcia dla osób z zaburzeniami psychicznymi (art. 20 ust. 1 pkt 2 u.p.s.). Wymienione zadania często będą łączyć się z przeciwdziałaniem problemom alkoholowym.

${ }^{82} \mathrm{Tj}$. regulacjami ustaw o pomocy społecznej, o zdrowiu publicznym, o działalności leczniczej i o świadczeniach opieki zdrowotnej finansowanych ze środków publicznych. 
2) samorządy wykonują zadania planistyczne - objęte treścią stosownych programów, jak i faktyczne polegające na profilaktyce, leczeniu i promocji zdrowia psychicznego;

3) charakter zdecentralizowanych zadań koresponduje z ustrojową rolą poszczególnych szczebli samorządu oraz

4) konstytucyjna zasada art. 15 ust. 1 w związku z realizacją zadań wymienionych w art. 68 ust. 1-3 oraz art. 69 Konstytucji RP nie znajduje precedensu w zadaniach publicznych z zakresu ochrony zdrowia psychicznego.

\section{Finansowanie świadczeń opieki zdrowotnej z zakresu zdrowia psychicznego ${ }^{83}$}

Zagadnienie finasowania świadczeń opieki zdrowotnej dotyczących zdrowia psychicznego jest o tyle istotne, że przekłada się bezpośrednio na realizację proklamowanej w art. 68 ust. 1 Konstytucji RP zasady równego dostępu do świadczeń opieki zdrowotnej finansowanych ze środków publicznych. Ustrojodawca nie zdecydował się - i słusznie - na wiążące ustalenie, czy świadczenia opieki zdrowotnej obejmujące szeroko pojętą opiekę psychiatryczną powinny być finansowane ze środków publicznych czy też nie. Założył, że kwestia ta powinna być przedmiotem decyzji ustawodawcy zwykłego. Jest to rozwiązanie właściwe już choćby z tego względu, że na „szerokość” opieki zdrowotnej finansowanej ze środków publicznych bezpośredni wpływ mają po pierwsze: „grubość portfela publicznego”, a po drugie: potrzeby obywateli. Oba czynniki a natura rei są zmienne. Ustawodawca zwykły ma bez wątpienia szybszy „współczynnik reakcji”, co pozwala adekwatnie w czasie odpowiadać na zmieniające się warunki. Potwierdzeniem tej ogólnej konkluzji jest treść art. 6 u.ś.z.p., który w zakresie zagwarantowania równego dostępu do świadczeń nakłada na władze publiczne obowiązek:

1) tworzenia warunków funkcjonowania systemu ochrony zdrowia;

2) analizowania i oceny potrzeb zdrowotnych oraz czynników powodujących ich zmiany;

${ }^{83}$ Autorem cz. 5 jest M. Kobak. 
3) promocji zdrowia i profilaktyki, mających na celu tworzenie warunków sprzyjających zdrowiu;

4) finansowania w trybie i na zasadach określonych ustawą świadczeń opieki zdrowotnej.

Opieka psychiatryczna i leczenie uzależnień zostały - wspólnie uznane za jeden rodzaj świadczeń opieki zdrowotnej - $\$ 2$ ust. 1 pkt 5 rozporządzenia Ministra Zdrowia z 8.09.2015 r. w sprawie ogólnych warunków umów o udzielanie świadczeń opieki zdrowotnej ${ }^{84}$. Wprawdzie treść art. 15 ust. 2 pkt 4 u.ś.z.p. ab initio może wprowadzać w błąd, sugerując, iż świadczenia w tym „przedmiocie” nie zostały wyodrębnione jako „rodzaj”, lecz jako „zakres” świadczeń opieki zdrowotnej, to jednak, ujmując rzecz systemowo, nie ma wątpliwości, iż kategorialnie wyodrębnia się je jako „rodzaj”. Powołany przepis kreuje tzw. pozytywny koszyk świadczeń gwarantowanych. Jego treść, na zasadzie enumeracji pozytywnej, rozstrzyga, jakie rodzaje świadczeń będą finansowane ze środków publicznych. Owo wyodrębnienie rodzajowe, z uwagi na swoją hasłowość, w zasadzie o niczym nie przesądza, nie można bowiem na jego podstawie kreować żadnych praw podmiotowych, treścią których byłoby żądanie udzielenia konkretnego świadczenia. W ustawie o świadczeniach opieki zdrowotnej finansowanych ze środków publicznych nie wymienia się bowiem konkretnych procedur medycznych (świadczeń), które są dostępne w ramach systemu, z uwagi na to, że da się je przypisać do rodzaju świadczeń dostępnych w ramach koszyka świadczeń gwarantowanych.

Wykaz świadczeń gwarantowanych udzielanych w rodzaju „opieka psychiatryczna i leczenie uzależnień” został ustalony przez Ministra Zdrowia w wydanym na podstawie art. 31d u.ś.z.p. rozporządzeniu z 6.11.2013 r. w sprawie świadczeń gwarantowanych z zakresu opieki psychiatrycznej i leczenia uzależnieńn ${ }^{85}$. Nasuwa się wobec tego pytanie, czy konstytucyjny wymóg ustawowego określenia zakresu świadczeń zdrowotnych finansowanych ze środków publicznych (art. 68

${ }^{84}$ Dz.U. z 2016 r. poz. 1146 ze zm. - dalej jako: rozporządzenie w sprawie ogólnych warunków umów o udzielanie świadczeń opieki zdrowotnej.

85 Dz.U. poz. 1386 ze zm. 
ust. 2 in fine Konstytucji RP) został zrealizowany. Wydaje się, że można tę kwestię zweryfikować pozytywnie, o ile ustawa precyzyjnie określa kryteria, w oparciu o które w reżimie „podustawowym” tworzy się katalog świadczeń dostępnych w ramach systemu.

Ustalenie zakresu świadczeń zdrowotnych udzielanych w ramach opieki psychiatrycznej i leczenia uzależnień bezpośrednio przekłada się na ich finansowanie, czego dowodzi treść $\$ 1$ pkt 17 załącznika do rozporządzenia w sprawie ogólnych warunków umów o udzielanie świadczeń opieki zdrowotnej. Z powołanej jednostki wynika, że zakresem świadczeń jest „świadczenie lub grupa świadczeń, dla których w umowie określa się kwotę finansowania”. Konkretyzacja wyodrębniająca dane świadczenia jako świadczenie finansowane zgodnie z normatywnym modelem nie jest dowolna, ma charakter złożony i konsultacyjno-ekspercki. Minister zobowiązany jest bowiem uzyskać w tym przedmiocie rekomendację Prezesa Agencji Oceny Technologii Medycznych i Taryfikacji. Agencja nie tylko kwalifikuje dane świadczenie jako gwarantowane, ale również określa poziom i sposób jego finansowania - art. 31n pkt 1 lit. a u.ś.z.p. Oceny tej Agencja dokonuje na podstawie zlecenia Ministra Zdrowia. Rola ministra nie jest tu czysto administracyjna, ponieważ zlecając sporządzenie rekomendacji, dokonuje jednocześnie opisu świadczenia zdrowotnego, a zatem konstruuje konkretną procedurę medyczną „aplikowaną” pacjentowi, którego dotknęła ściśle określona jednostka chorobowa i który znajduje się w ściśle określonym stanie zdrowia. Jest również zobowiązany podać, jaki wpływ na stan zdrowia pacjenta będzie miało skorzystanie przez niego z danego świadczenia - art. 31c ust. 1 u.ś.z.p. Agencja nie dokonuje więc jedynie abstrakcyjnej oceny metodologicznej poprawności konstrukcji danej procedury medycznej z zakresu zdrowia psychicznego i leczenia uzależnień, ale także jej przydatności z perspektywy zdrowia pacjentów. W swoim działaniu Agencja nie jest w pełni samodzielna, gdyż i ona zobowiązana jest zasięgnąć opinii:

1) konsultanta krajowego (konsultantów krajowych) z dziedziny psychiatria (psychiatria dzieci i młodzieży);

2) Prezesa Narodowego Funduszu Zdrowia. 
Pierwszy podmiot ocenia dane świadczenie merytorycznie, drugi natomiast określa skutki finansowe, jakie wywoła dla systemu ochrony zdrowia zakwalifikowanie go jako świadczenia gwarantowanego. Ustawa zakreśla podmiotom zobowiązanym do wydania opinii stosunkowo krótki termin, jedynie bowiem 30 dni - art. 31c ust. 4 u.ś.z.p. Nie rozstrzyga jednocześnie o skutkach niewydania opinii w terminie bądź niewydania jej w ogóle. Przyjąć należy, że termin ten ma charakter jedynie instrukcyjny, a sama opinia jest niezbędnym elementem legitymizującym Prezesa Agencji do dalszego procedowania. Uzyskawszy obie opinie, Prezes przekazuje je Radzie Przejrzystości. Jest to ciało opiniodawczo-doradcze działające przy Prezesie Agencji - art. 31s ust. 1 u.ś.z.p. Rada przedstawia Prezesowi Agencji swoje stanowisko w sprawie:

1) zakwalifikowania danego świadczenia opieki zdrowotnej jako świadczenia gwarantowanego wraz z określeniem poziomu lub sposobu jego finansowania albo

2) niezasadności zakwalifikowania danego świadczenia opieki zdrowotnej jako świadczenia gwarantowanego.

Prezes Agencji, wydając rekomendację ministrowi, „bierze pod uwagę stanowisko" Rady Przejrzystości - art. 31c ust. 7 u.ś.z.p. Zasadna wydaje się teza, że takie sformułowanie regulacji ustawowej kreuje de facto obowiązek Prezesa Agencji do wydania rekomendacji treściowo skorelowanej ze stanowiskiem Rady. Pewności już takiej nie ma na kolejnym etapie procesu decyzyjnego, a mianowicie wówczas, gdy Minister Zdrowia, dysponując już rekomendacją Prezesa Agencji, ma ostatecznie rozstrzygnąć o zakwalifikowaniu danego świadczenia jako gwarantowanego. Jak wynika z treści art. $31 b$ ust. 1 u.ś.z.p. minister podejmuje w tym zakresie decyzję po uzyskaniu rekomendacji i przy uwzględnieniu kryteriów określonych w art. 31a u.ś.z.p. Otrzymanie rekomendacji kwalifikować należy raczej jako prawnie zadekretowany element procesu kwalifikacji świadczenia jako gwarantowanego, bezpośrednio poprzedzający podjęcie w tym przedmiocie decyzji przez Ministra Zdrowia. Treść rozwiązań ustawowych nie przemawia za konkluzją o związaniu ministra rekomendacją. Wniosek ten można argumentacyjnie wesprzeć, jeżeli uwzględni się fakt, że minister przy kwalifikacji świadczenia jako gwarantowanego jest 
zobowiązany wziąć pod uwagę kryteria określone w art. 31a u.ś.z.p., a zatem te same kryteria, które uwzględnia Prezes Agencji przy wydawaniu rekomendacji. Z formalno-logicznej perspektywy uwzględnianie tych kryteriów przez ministra nie miałoby sensu, gdyby był on związany rekomendacją Prezesa Agencji. Rekomendacja ta ma bowiem te kryteria uwzględniać, stąd ponowna ich analiza, w sytuacji gdyby minister był zobligowany uwzględnić jej treść, pozbawiona byłaby racjonalnego uzasadnienia.

Zakwalifikowanie świadczenia zdrowotnego z zakresu opieki psychiatrycznej i leczenia uzależnień do koszyka świadczeń gwarantowanych, zgodnie z wcześniejszymi uwagami, mają uzasadniać kryteria sformułowane w treści art. 31a ust. 1 u.ś.z.p. Zostały one podzielone na siedem grup:

1) wpływ na poprawę zdrowia obywateli;

2) skutki następstw choroby lub stanu zdrowia;

3) znaczenie dla zdrowia obywateli;

4) skuteczność kliniczna i bezpieczeństwo;

5) stosunek uzyskiwanych korzyści zdrowotnych do ryzyka zdrowotnego;

6) stosunek kosztów do uzyskiwanych efektów zdrowotnych;

7) skutki finansowe dla systemu ochrony zdrowia, w tym dla podmiotów zobowiązanych do finansowania świadczeń opieki zdrowotnej ze środków publicznych.

W ramach pierwszego kryterium ustawodawca uznał za istotne priorytety zdrowotne oraz wskaźniki zapadalności, chorobowości lub śmiertelności określone na podstawie aktualnej wiedzy medycznej. Priorytety zdrowotne w drodze rozporządzenia określa Minister Zdrowia, mając na uwadze stan zdrowia obywateli oraz uzyskanie efektów zdrowotnych o najwyższej wartości - art. 31a ust. 2 u.ś.z.p. Realizując przedmiotową delegację, minister wydał rozporządzenie z 27.02.2018 r. w sprawie priorytetów zdrowotnych. Jak wynika z jego treści, do wzmiankowanych priorytetów zaliczono zapobieganie, leczenie i rehabilitację zaburzeń psychicznych oraz ograniczanie następstw zdrowotnych spowodowanych stosowaniem substancji psychoaktywnych lub uzależnieniem od tych substancji - $\$ 1$ pkt 4 i 5 . 
Określenie priorytetów zdrowotnych nie jest działaniem bezrefleksyjnym, pozbawionym prakseologicznych podstaw. $Z$ delegacji upoważniającej do wydania rozporządzenia wynika expressis verbis, że minister, ustalając merytoryczną treść rozporządzenia, ma obowiązek uwzględnić stan zdrowia obywateli oraz uzyskanie efektów zdrowotnych o najwyższej wartości. O ile ostatni z wymogów zostaje „skonsumowany" w momencie uzyskania rekomendacji Prezesa Agencji, o tyle nie jest na pierwszy rzut oka jasne, w jaki sposób pozyskuje wiedzę co do stanu zdrowia obywateli. Wyjaśnienie tej kwestii znajduje się w treści art. 95a u.ś.z.p. Podany przepis określa tryb i zasady sporządzania Regionalnych Map Potrzeb Zdrowotnych i Ogólnopolskiej Mapy Potrzeb Zdrowotnych. Są to instrumenty, przy pomocy których Minister Zdrowia pozyskuje informacje o stanie zdrowia obywateli, co z kolei pozwala mu wdrożyć „skuteczne narzędzia planowania zabezpieczenia właściwej dostępności do świadczeń opieki zdrowotnej, z uwzględnieniem specyfiki potrzeb zdrowotnych społeczności lokalnych" - art. 95a ust. 11 u.ś.z.p. Mapy Regionalne sporządzają wojewodowie w oparciu o projekty stworzone przez Narodowy Instytut Zdrowia Publicznego - Państwowy Zakład Higieny. Mapy sporządza się przy wykorzystaniu danych epidemiologicznych, demograficznych i danych $\mathrm{z}$ rejestru podmiotów wykonujących działalność leczniczą. Mapę Ogólnopolską tworzy się w oparciu o Mapy Regionalne z wszystkich województw. Po zatwierdzeniu map przez Ministra Zdrowia publikuje się je na stronach Biuletynu Informacji Publicznej urzędu obsługującego ministra oraz urzędów obsługujących wojewodów. Szczeblowość sporządzania map potrzeb zdrowotnych wyraźnie dowodzi pewnej decentralizacji, którą należy uzasadniać tym, że na szczeblu regionalnym z pewnością dostęp do danych i analiza potrzeb społeczności lokalnych są dużo łatwiejsze i szybsze niż na szczeblu centralnym.

Z przedstawionych uwag wyłania się konkluzja, że proces decyzyjny co do objęcia konkretnych świadczeń opieki zdrowotnej z zakresu opieki psychiatrycznej i leczenia uzależnień finansowaniem ze środków publicznych jest złożony, wieloetapowy i angażujący różne podmioty, tak na szczeblu centralnym, jak i regionalnym. Przyjęte rozwiązania normatywne, w swych pryncypiach, należy ocenić jako racjonalne i odpowiadające wyzwaniom, jakie rodzi konieczność re- 
agowania na zmieniające się potrzeby obywateli, zasobność portfela publicznego, nowe metody medycznej pomocy czy też aktualizacje kosztochłonności poszczególnych świadczeń.

W kwestii decentralizacji procesu finasowania świadczeń zdrowotnych z zakresu zdrowia psychicznego należy podać, że przejawia się ona niejako dwupłaszczyznowo: po pierwsze, już w samym fakcie zdecentralizowania „płatnika”, poprzez stworzenie wojewódzkich oddziałów narodowego funduszu zdrowia, i po drugie, poprzez przeniesienie obowiązku finansowania niektórych świadczeń na samorządy. Wojewódzką lokację oddziałów funduszu należy uzasadniać lepszym zorientowaniem na uwarunkowania lokalne, jak też usprawnieniem postępowań wyłaniających podmioty udzielające świadczeń finansowanych ze środków publicznych; z przyczyn oczywistych będzie to łatwiejsze w skali regionu niż w skali kraju. Rozdysponowując pulę przyznanych środków publicznych na poszczególne zakresy i rodzaje świadczeń, wojewódzki oddział NFZ kieruje się ustalonymi potrzebami zdrowotnymi w regionie oraz potencjałem (przyszłych) świadczeniodawców.

Odrębnej charakterystyki finansowania wymagają szeroko pojęte programy z zakresy ochrony zdrowia psychicznego. I w tym wypadku wdrożono bowiem różnego rodzaju zdecentralizowane/zdywersyfikowane instrumenty pozyskiwania środków na ich realizację. Narodowy Program Ochrony Zdrowia Psychicznego na lata 2017-2022 wymaga finansowego udziału Narodowego Funduszu Zdrowia, poszczególnych ministerstw (Sprawiedliwości, Obrony Narodowej, Spraw Wewnętrznych i Administracji, Rodziny, Pracy i Polityki Społecznej), jak i jednostek samorządu terytorialnego wszystkich szczebli. O ile nakłady Funduszu oraz poszczególnych ministerstw zostały sparametryzowane kwotowo w poszczególnych latach aktywności programu, o tyle zakres udziału finansowego jednostek samorządu terytorialnego jest nieokreślony, opatrzono go natomiast zastrzeżeniem, iż ma być adekwatny do potrzeb wynikających z zadań (własnych), jakie $\mathrm{w}$ ramach programu jednostki te realizują.

Analogiczny model finansowania przewidziano w ramach świadczeń udzielanych na gruncie ustawy o przeciwdziałaniu narkomanii. W za- 
leżności od charakteru zadań w tym zakresie są one finansowane albo ze środków własnych podmiotów, które je realizują, środków przeznaczonych na realizację programów, o których mowa w art. 48 ust. 1 u.ś.z.p., oraz środków Narodowego Funduszu Zdrowia innych niż przeznaczone na realizację programów zdrowotnych ${ }^{86}$. Wyodrębniono również grupę zadań finansowanych ze środków budżetu państwa pozostających w dyspozycji właściwych ministrów ${ }^{87}$. Również w odniesieniu do działań podejmowanych w ramach działalności wdrożeniowej Narodowego Programu Zdrowia w latach 2016-2020 przewidziano częściową decentralizację finasowania; te zadania, które zostały przekazane jednostkom samorządu terytorialnego jako zadania własne finansowane są ze środków tych jednostek. Z kolei zadania powierzane do realizacji w trybie konkursowym lub wnioskowym, o których mowa w art. 14 ust. 1 i 2 u.z.p., są finansowane ze środków planowanych przez odpowiednich dysponentów części budżetowych lub w ramach rocznych planów finansowych funduszy celowych, o których mowa w art. 29 ustawy z 27.08.2009 r. o finansach publicznych ${ }^{88}$, zgodnie z limitami określonymi przez ministra właściwego do spraw zdrowia, jako koordynującego realizację zadań z zakresu zdrowia publicznego.

Odmienny model finansowania nie obowiązuje również na gruncie zadań realizowanych w oparciu o przepisy ustawy o wychowaniu w trzeźwości i przeciwdziałaniu alkoholizmowi. I w tym wypadku część zadań finasowana jest z budżetu państwa; będą to zadania realizowane przez podległą Ministrowi Zdrowia Państwową Agencję Rozwiązywania Problemów Alkoholowych, a część finansowana jest ze środków samorządu województwa i samorządu gminy, adekwatnie do nałożonych na te jednostki obowiązków - art. 4 i $4^{1}$ u.w.t.

${ }^{86}$ Do zadań tych u.ś.z.p. zalicza: 1) działalność wychowawczą, edukacyjną, informacyjną i profilaktyczną; 2) leczenie, rehabilitację i reintegrację osób uzależnionych; 3) ograniczanie szkód zdrowotnych i społecznych.

${ }^{87}$ Są to następujące zadania: 1) nadzór nad substancjami, których używanie może prowadzić do narkomanii; 2) zwalczanie niedozwolonego obrotu, wytwarzania, przetwarzania, przerobu i posiadania substancji, których używanie może prowadzić do narkomanii; 3) nadzór nad uprawami roślin zawierających substancje, których używanie może prowadzić do narkomanii.

${ }^{88}$ Dz.U. z 2017 r. poz. 2077 ze zm. 
Z podanych rozwiązań wyłania się oczywisty paradygmat decentralizacji finansowania świadczeń opieki zdrowotnej z zakresu zdrowia psychicznego; przekazanie do realizacji określonej części zadań jednostkom samorządu terytorialnego pociąga za sobą obowiązek ich finansowania. Można oczywiście detalizować poszczególne rozwiązania i roztrząsać, czy konkretne zadanie nie powinno zostać ulokowane centralnie (i vice versa). Wydaje się jednak, że leitmotiv w tym obszarze był taki, aby decentralizować te zadania, które są uwarunkowane endemicznie, co niewątpliwie zasługuje na aprobatę.

\section{Bibliografia:}

Boć J., Lisowski P., Normatywizacja wartości w prawie administracyjnym [w:] Wartości w prawie administracyjnym, red. J. Zimmermann, Warszawa 2015 Callach D., Health and Society: Same Ethical Imperatives, „Deadalus” 1977/106/1 Complak K., Preambuły do konstytucji [w:] Prawniczy słownik wyrazów trudnych, red. J. Boć, Wrocław 2005

Crithley M., Butterworths Medical Dictionary, Londyn 1978

Dercz M., Samorząd terytorialny w systemie ochrony zdrowia, Warszawa 2005

Dercz M., Izdebski H., Organizacja ochrony zdrowia w Rzeczypospolitej Polskiej w świetle obowiazujacego ustawodawstwa, Warszawa-Poznań 2001

Dobra chronione w prawie administracyjnym, red. Z. Duniewska, Łódź 2014

Frąckiewicz L., Polityka ochrony zdrowia - synteza, Katowice 1991

Fundowicz S., Decentralizacja administracji publicznej w Polsce, Lublin 2005

Indulski J., Leowski J., Podstawy medycyny społecznej, Warszawa 1971

Izdebski H., Kulesza M., Administracja publiczna. Zagadnienia ogólne, Warszawa 2004

Jaroszyński M., Wspótpraca z rządem w samorządzie, „Gazeta Polska” 1934/44 Jeżewski J., Podział kompetencji między samorzad terytorialny a państwo we Francji, ST 1992/3

Kallas M., Lipowicz I., Niewiadomski Z., Szpor G., Prawo administracyjne. Część ustrojowa, Warszawa 2003

Kant J.W., Biologiczne podstawy psychologii, Warszawa 2011

Konstytucje Rzeczypospolitej Polskiej oraz komentarz do Konstytucji RP z 1997 roku, red. J. Boć, Wrocław 1998 
Lalond M., A New Perspective on Health of Canadians, a work document, Ministry of Supply and Services of Canada, Ottawa 1978

Latoszek E., Proczek M., Organizacje międzynarodowe. Założenia, cele, działalność, Warszawa 2001

Leoński Z., Zarys prawa administracyjnego, Warszawa 2004

Leowski J., Polityka zdrowotna - dylematy $i$ wyzwania reformy ochrony zdrowia w Polsce i na świecie, „Prawo i Medycyna” 1999/2

Lewandowski S., Kontrowersje wokół preambuł, „Studia Iuridica” 1996/31

Longstaff A., Neurobiologia, Warszawa 2002

Niewiadomski Z., Polski samorząd terytorialny w świetle standardów europejskich, ST 1992/11

Niewiadomski Z., Samorząd terytorialny w warunkach współczesnego państwa kapitalistycznego, Warszawa 1988

Nosko J., Promocja zdrowia i ochrona zdrowia jako zadania własne samorzadu terytorialnego - cz. 1, „Zdrowie Publiczne” 2000/4

Nosko J., Promocja zdrowia i ochrona zdrowia jako zadania własne samorzadu terytorialnego - cz. 2, „Zdrowie Publiczne” 2000/5

Nowacka E., Spór o pojęcie samorządu terytorialnego $w$ doktrynie prawnej okresu międzywojennego, ST 1992/4

Olejniczak-Szałowska E., Zadania własne i zlecone samorzadu terytorialnego, ST 2000/12

Oniszczuk J., Konstytucja Rzeczypospolitej Polskiej w orzecznictwie Trybunału Konstytucyjnego na początku XXI w., Kraków 2004

Organizacja ochrony zdrowia, red. J. Indulski, Warszawa 1984

Pańko W., Nie przeceniam swojej roli, „Wspólnota” 1991/43

Piekara A., Wartość, istota, uwarunkowania i funkcje społeczne samorządu terytorialnego a rozwój lokalny [w:] Samorząd terytorialny a rozwój lokalny, red. A. Piekara, Z. Niewiadomski, Warszawa 1992

Podgórski K., Ustawowa regulacja zadań gmin jako jednostki samorządu terytorialnego, ST 1991/11-12

Posłuszny J., O nowej koncepcji administracji świadczacej [w:] Aktualne problemy administracji i prawa administracyjnego, red. Z. Leoński, Z. Niewiadomski, J. Posłuszny, J. Stelmasiak, J. Szreniawski, K. Ziemski, L. Żukowski, Przemyśl-Rzeszów 2003

Prawo administracyjne, red. J. Boć, Wrocław 2000

Seligman M., Walker E., Rosenhan D., Psychopatologia, Poznań 2003 
Stahl M., Szczegółowe prawne formy działania administracji [w:] System Prawa Administracyjnego, t. 5, Prawne formy działania administracji, red. R. Hauser, Z. Niewiadomski, A. Wróbel, Warszawa 2013

Starościak J., Decentralizacja administracji, Warszawa 1960

The Future of Public Health, Committee for the Study of the Future of Public Health, Institute of Medicine, Washington D.C. 1988

Tykwińska-Rutkowska D., Ochrona życia i zdrowia człowieka w prawie administracyjnym (przyczynek do dyskusji) [w:] Dobra chronione w prawie administracyjnym, red. Z. Duniewska, Łódź 2014

Ustrój administracji publicznej, red. J. Szreniawski, Lublin 1995

Webster's Medical Dictionary, Springfield 1986

Wegner-Kowalska J., Zdrowie człowieka jako przedmiot ochrony prawa administracyjnego [w:] Dobra chronione w prawie administracyjnym, red. Z. Duniewska, Łódź 2014

Wiktorowska A., Prawne determinanty samodzielności gminy. Zagadnienia administracyjnoprawne, Warszawa 2002

Winczorek P., Komentarz do Konstytucji Rzeczypospolitej Polskiej z 2.04.1997 r., Warszawa 2000

Włodarczyk C., Polityka zdrowotna w społeczeństwie demokratycznym, Łódź-Kraków-Warszawa 1996

Włodarczyk C., Paździoch S., Pojęcie i zakres zdrowia publicznego [w:] Zdrowie publiczne, red. A. Czupryna, C. Włodarczyk, t. 1, Kraków 2000

Włodarczyk C., Paździoch S., Systemy zdrowotne - zarys problematyki, Kraków 2001 